\title{
A EMENDA CONSTITUCIONAL 45 E A QUESTÃO DO ACESSO À JUSTIÇA
}

\author{
Ludmila Ribeiro
}

THE CONSTITUTIONAL AMENDMENT 45 AND THE ACESS TO THE JUSTICE

\section{RESUMO}

A PROPOSTA DESTE ARTIGO É DISCUTIR EM QUE MEDIDA A EMENDA CONSTITUCIONAL 45 PODE (OU NÃO) ALTERAR O CENÁRIO ATUAL DE ACESSO À JUSTIÇA ATRAVÉS DA ALTERAÇÃO DE ALGUMAS NORMAS RELATIVAS AO FUNCIONAMENTO DO JUDICIÁRIO BRASILEIRO. ESTE ESTUDO SE INSERE NA SEARA DENOMINADA "DIREITO E SEGURANÇA JURÍDICA" NA MEDIDA EM QUE PRETENDE VERIFICAR DE QUE FORMA ALTERAÇÕES LEGAIS PODEM O ESCOPO E O TIPO DE ACESSO QUE A POPULAÇ̃̃O POSSUI AO JUDICIÁRIO. PARA TANTO, ALÉM DE UMA REVISÃO SOBRE O PROCESSO DE CONSTITUIÇÃO E REFORMA DO SISTEMA JUDICIÁRIO BRASILEIRO, SOBRE OS PRESSUPOSTOS TEÓRICOS DA QUESTÃO DO ACESSO À JUSTIÇA, ESTE ARTIGO REVISOU OUTRAS PESQUISAS NACIONAIS SOBRE CADA UM DOS TEMAS ESCOLHIDOS PARA ESTA ABORDAGEM NO ÂMBITO DESSA EMENDA. AS CONCLUSÕES APONTAM PARA O FATO DE QUE VÁRIAS DAS MUDANÇAS PREVISTAS PELA EC/45 PODERIAM SER MATERIALIZADAS PELO SIMPLES CUMPRIMENTO DA LEGISLAC̣ÃO EXTRAORDINÁRIA JÁ EXISTENTE. NESSE SENTIDO, A GRANDE ALTERAÇÃO INSTITUÍDA PELA EMENDA 45 FOI A CONSTITUIÇÃO DO Conselho Nacional de Justiça como órgão destinado a AVALIAR O TRABALHO DAS CORTES ESTADUAIS DE JUSTIÇA.

\section{PALAVRAS-CHAVE}

Emenda Constitucional 45; Análise Institucional; Acesso À Justiça; REFORMA Judicial

\section{ABSTRACT}

THIS ARTICLE ANALYSIS THE 45TH AMENDMENT TO THE BRAZILIAN CONSTITUTION, FOCUSING ON THE POSSIBILITIES THAT THIS RULE HAS IN ENLARGE THE ACCESS TO THE JUSTICE IN THIS COUNTRY. THIS STUDY IS RELATED TO THE AREA "RIGHT AND LEGAL SECURITY" BECAUSE IT IS GOING TO VERIFY IF THIS LAWFUL ALTERATION IS ABLE TO IMPROVE THE ACCESS THAT THE PEOPLE HAS TO THE BRAZILIAN JUDICIARY. THEREFORE, BEYOND A REVISION ABOUT THE CONSTITUTION AND REFORMS OF THE BRAZILIAN JUDICIAL SYSTEM AND THE THEORETICAL FRAMEWORK RELATED TO THE ACCESS TO THE JUSTICE, THIS ARTICLE OVERHAULED OTHER RESEARCHES ABOUT THE ROUTINE AND ORGANIZATIONAL STRUCTURE OF THE JUDICIARY STATE COURTS. THE RESULTS AIM THAT, DESPITE THE 45TH

CONSTITUTIONAL AMENDMENT INTENDS TO CHANGES THE JUDICIARY SYSTEM AS A ROLE; SOME OF ITS DISPOSITION THOSE COULD BE DONE THROUGH THE FULFILLMENT OF THE EXISTING EXTRAORDINARY LEGISLATION. THEREFORE, THE NATIONAL COUNCIL OF JUSTICE APPEARS TO BE THE MAJOR TRANSFORMATION IN THAT SCENARIO.

\section{KEYWORDS}

CONSTITUTIONAL AMENDMENT 45; INSTITUTIONAL ANALYSIS, ACCESS to JUSTICE; JUdiCIAL REFORM

\section{INTRODUÇÃO}

$\mathrm{Na}$ atualidade, boa parte das discussões a respeito da legitimidade do Poder Judiciário como instrumento de pacificação dos conflitos sociais diz respeito ao acesso que a população tem ao mesmo. Parte-se do pressuposto de que, se a população não possuir 
mecanismos efetivos de acesso à justiça, a resolução das controvérsias existentes na sociedade ocorrerá no âmbito privado. Entre os principais entraves ao acesso da população à justiça destacam-se a excessiva duração dos processos, a complexidade dos procedimentos judiciais e a falta de transparência na prestação jurisdicional.

A Emenda Constitucional 45 pode ser entendida, nesse cenário, como um diploma legal promulgado com o objetivo de resolver os três problemas apresentados supra, entendidos como as mais importantes limitações na questão do acesso à justiça. Para uma melhor compreensão das principais alterações que esse diploma institui e os principais problemas que ela pretende solucionar (VER QUADRO 1). ${ }^{1}$

Tendo como ponto de partida o arcabouço sumarizado no Quadro 1, que apresenta os problemas contextuais do acesso à justiça e as mudanças institucionais que a EC/45 estabelece, o argumento a ser desenvolvido neste artigo é: "Em que medida a instituição das alterações organizacionais sumarizadas na coluna 2 [Instituto da EC 45 que procura resolvê-lo] do quadro em questão, no âmbito do poder judiciário, podem aumentar o acesso que os cidadãos brasileiros têm à justiça?”.

Nesses termos, como a lei estabelece certos mecanismos e estabelece ainda um órgão responsável pelo acompanhamento de tais mecanismos, a proposta aqui é verificar em que medida esse sistema de pesos e contrapesos proposto pela Emenda Constitucional 45 pôde ser institucionalizado na realidade dos Tribunais Estaduais e em que medida ele tem permitido a ampliação do acesso à justiça.

Para tanto, o termo acesso à justiça será, no âmbito deste artigo, entendido como a possibilidade de todos os cidadãos não apenas recorrerem ao poder judiciário para buscar uma solução institucional dos seus conflitos como ainda a possibilidade de terem o seu conflito resolvido pelo judiciário no menor espaço de tempo e com o menor custo social (Junqueira, 1996). Ou seja, não se pretende aqui avaliar a eficácia ou efetividade das reformas introduzidas pela Emenda Constitucional n. 45 , porque o tempo transcorrido entre a sua publicação e o cenário atual ainda é bastante restrito (apenas dois anos). O objetivo é discutir a sua capacidade em de fato alterar a realidade cotidiana dos tribunais estaduais e, com isso, introduzir de fato uma mudança no cenário institucional do judiciário capaz de ampliar o aceso à justiça.

$\mathrm{Na}$ tentativa de responder à questão que orienta essa reflexão, este artigo encontra-se dividido em quatro seções: na primeira são apresentados os traços característicos do sistema judicial brasileiro, fundamental para a compreensão de qualquer reforma que tenha como proposta alterar as bases de sustentação do funcionamento institucional do Poder Judiciário. Em seguida, são discutidas as definições de acesso à justiça, conceito que a EC 45/04 pretende materializar por meio da alteração de princípios constitucionais. Na terceira parte do trabalho cada uma das alterações é objeto de considerações detalhadas que visam analisar em que medida essas mudanças se fazem viáveis ou não na realidade do judiciário brasileiro. 
Por fim, são apontadas tanto as novas possibilidades como os limites para a ampliação efetiva do acesso da população ao Poder Judiciário (ou “à justiça”).

\section{A constituição do Sistema Judicial Brasileiro}

Diversos estudos apontam as características do Estado brasileiro a partir de sua formação e a influência da cultura portuguesa no modo de administração da justiça (FAORO, 2004; PRADO JÚNIOR, 1994; HOLANDA, 2004; DAMATTA, 1979).

Essa viagem histórica ao período da colonização e em especial ao período do Reino Unido de Portugal, Brasil e Algarves (1815 a 1822), quando a corte portuguesa se transfere para o Brasil dada a probabilidade de invasão do Estado português em razão das guerras napoleónicas (OLIVEIRA, 2005). Com isso, tem-se a imposição de uma ossatura institucional do judiciário português nas terras brasileiras sem correspondência com a realidade da colônia.

Esse descolamento fez com que, especialmente no âmbito do judiciário, se verificasse a famosa distinção entre o "país formal”, cuja existência se verifica na constituição e nos códigos legais e o "país real" que segue alheio e à margem dos direitos preconizados pelas leis. Se, quando houve a instituição do Estado, esperava-se que esse anacronismo fosse superado com o passar do tempo, na realidade atual, percebe-se a dificuldade de sua superação (SHIRLEY, 1987).

Soma-se a isso o fato de que, em razão dessa transferência, a formação do Estado brasileiro seguiu as mesmas premissas de centralização, regulações embaralhadas, além da forte influência da Igreja no Estado Português. A hierarquia complexa e confusa, composta de muitos auxiliares, valendo-se da proximidade com a Coroa para o exercício do poder, fez com que a administração pública se estruturasse com uma base institucional que, na teoria, sobrevalorizava o caráter jurídico da ação pública mas, socialmente, pautava-se no sistema de privilégios personalistas da corte lusitana (SCHWARTZ, 1979).

Relatos históricos como os de João Almeida Júnior (1920), Schwartz (1979), Holanda (2004) e Prado Júnior (1994) revelam as dificuldades da administração judicial nos primórdios de sua instituição, que, além de encarregada da justiça, era também responsável por encargos burocráticos e administrativos da colônia. Soma-se a isso o fato de que em razão da forma de organização da administração da justiça, muitas vezes, o braço da lei não chegava a áreas remotas e a esparsa colonização tinha como resultado a falta de pressão comunitária para apoiar a moralidade e o respeito pela lei.

O problema dessa questão é que ela não ficou circunscrita ao período do Reino Unido de Portugal, Brasil e Algarves, permanecendo, inclusive, após o retorno da corte ao país de origem e ainda após a independência e instalação da monarquia no Brasil. Assim, analisando o período imperial (1822 a 1890) é possível afirmar que o braço da lei continuava a não se fazer fisicamente presente em algumas localidades e, 
em outras, a sua presença era sentida de maneira distinta por aqueles que habitavam a região, dado o fato de que as práticas do sistema judicial brasileiro no século XIX reforçaram as características de categorização elitista e excludente, baseadas em uma suposta incapacidade da população brasileira para discernir, em termos de sua participação, a definição das práticas políticas e sociais no país.

Com a proclamação da república tem-se a instituição do sistema de justiça brasileiro tal como hoje o conhecemos. Consolidou-se a idéia de um sistema composto por diversas organizações burocráticas, segmentadas de acordo com a matéria que processam, e funcionando, teoricamente, de acordo com as regulamentações dos diversos códigos publicados ou reforçados a partir do fim do império. Como efeito direto dessa institucionalização, tem-se a prerrogativa de que o acesso à justiça passaria a ser orientado pelo domínio do racional-legal vislumbrado, primordialmente, na impessoalidade, formalismo, centralização, profissionalização, especialização e documentação (SAPORI, 1995).

Kant de Lima (2000), ao analisar a trajetória do sistema judicial durante o período republicano (1890 até hoje), qualifica-o como uma referência dual, como a própria discussão da sociedade brasileira caracterizada por DaMatta (1979). Dessa forma, a administração judicial brasileira, ainda na atualidade, pode ser entendida "como universo simbólico em que a desigualdade é naturalizada, por oposição ao explícito discurso político e democrático”. Ainda hoje o modelo burocrático implantado quando da instituição do Reino Unido de Portugal, Brasil e Algarves, em termos de sua racionalidade, mantém os traços do ethos patrimonialista, gerando uma modernização incompleta, ressabiada, deslocada e ressentida da política.

Nos últimos anos, contudo, esse aparato tem "sofrido" ou "passado por" mudanças substanciais em sua forma de funcionamento, em uma tentativa de promover a solução dos conflitos que são levados à arena judicial. Tais transformações são, por sua vez, refratárias de um fenômeno maior: as alterações vividas pela sociedade brasileira, principalmente, no que se refere à incapacidade da justiça do tipo "linha de montagem" em conseguir processar adequadamente os conflitos que chegam ao seu conhecimento.

Assim, a partir do início da década de 1990, várias foram as legislações que procuraram dotar o sistema judicial brasileiro de requisitos que o permitissem atuar como órgão calibrador de tensões sociais, solucionando conflitos de maneira ágil, menos complexa e mais transparente. Em conseqüência, houve mudanças nos escopos da ação, do processo e da jurisdição, no intuito de que o judiciário se consubstanciasse em uma instituição apta a mediar conflitos de interesses e tensões sociais. Dentre as principais mudanças introduzidas no funcionamento do sistema judicial brasileiro nos últimos anos tem-se a criação dos juizados cíveis e criminais; a publicação da Emenda Constitucional n. 22, a criação dos Juizados de Violência Doméstica e Familiar e a Emenda Constitucional n. 45. 
De acordo com Letterielo (2005), os juizados especiais cíveis e criminais ${ }^{2}$ (conhecidos também como juizados de pequenas causas), foram idealizados e implantados para facilitar o acesso à Justiça pela população carente, pela grande massa de hipossuficientes, principalmente aqueles que sofrem desigualdades sociais e que, desprovidos de recursos para enfrentar os custos do processo, dificilmente ou quase nunca recorrem ao judiciário à busca de proteção aos seus interesses violados ou ameaçados de violação.

No bojo dessa reforma, tem-se ainda a publicação da Emenda Constitucional 22, de 18.03.1999, a qual acrescentou o parágrafo único, ao art. 98 da Constituição, possibilitando à Lei Federal dispor sobre a criação de Juizados Especiais na Justiça Federal. Vale dizer, a Emenda Constitucional autorizou, por lei federal, a criação de Juizados Especiais, na Justiça Federal, o que procedido pelo art. $1^{\mathrm{O}}$, da Lei 10.259/2001 (FONTANA, 2002).

A Lei 11.340, de 07.08.2006, por sua vez, retirou dos Juizados Especiais Criminais a competência pelas infrações de menor potencial ofensivo cometidas contra a mulher no âmbito doméstico ou familiar. Nesses casos, o processamento e o julgamento ocorrem perante os Juizados de Violência Doméstica e Familiar contra a Mulher. ${ }^{3}$

Reformas menores também foram introduzidas com o objetivo de reduzir a lentidão dos processos, a morosidade da justiça e a ineficácia de muitos provimentos judiciais, sendo que, conforme pontuado por Hertel (2005), cabe destacar as realizadas pelas leis: 9494/97 (que generalizou a antecipação de tutela); 10352/01 (reforma do sistema recursal); 10358/01 (que alterou preceptivos do processo do conhecimento); e 10444/02 (que alterou substancialmente o processo de execução).

A partir de todas essas reformas, percebeu-se, contudo, a disparidade existente entre a estrutura do Judiciário e os avanços sociais, bem como a necessidade de ser realizada uma mudança mais abrupta não apenas da legislação infraconstitucional, mas do próprio texto constitucional, especialmente no que diz respeito aos problemas da morosidade processual, complexidade dos procedimentos judiciais e falta de transparência na prestação jurisdicional. Tal tarefa foi realizada pelo constituinte derivado que elaborou a Emenda Constitucional 45, a qual foi promulgada em 08.12.2004 (HERTEL, 2005).

A Emenda Constitucional 45/04 procurou não apenas ampliar mas, ainda, consolidar os processos de reforma já iniciados a partir das mudanças citadas. Esta teve como objetivo a aumentar a capilaridade do sistema judicial brasileiro, tornando-o mais acessível e ágil, viabilizando a solução institucional de certos conflitos que, em razão do excesso de tempo e da distância da justiça, terminavam por ser resolvidos na arena privada. Entre as principais alterações introduzidas por essa legislação, no que diz respeito ao funcionamento da justiça, destacam-se as seguintes: (i) razoável duração do processo; (ii) proporcionalidade entre o número de juízes na unidade jurisdicional e a efetiva demanda judicial e a respectiva população; (iii) funcionamento 
ininterrupto da atividade jurisdicional; (iv) distribuição imediata dos processos em todos os graus de jurisdição; e (v) criação do Conselho Nacional de Justiça.

Essas alterações introduzidas na sistemática de funcionamento do sistema judicial brasileiro têm como finalidade não apenas viabilizar o acesso à Justiça enquanto instituição estatal, mas viabilizar o acesso à ordem jurídica justa, a qual se caracteriza pelo direito à informação; pelo direito à adequação entre a ordem jurídica e a realidade socioeconômica do País; pelo direito ao acesso a uma justiça adequadamente organizada, formada por juízes inseridos na realidade social e comprometidos com o objetivo de realização da ordem jurídica justa; pelo direito à pré-ordenação dos instrumentos processuais capazes de promover a objetiva tutela dos direitos; e pelo direito à remoção dos obstáculos que se anteponham ao acesso efetivo a uma justiça que tenha tais características (WATANABE, 1996).

Assim, para que o entendimento dessas inovações ocorra a partir da perspectiva de democratização do sistema judicial brasileiro, faz-se indispensável uma breve conceituação da expressão “acesso à justiça”.

\section{A PROBLEMÁticA dA DEFINiÇÃo DE ACESSO À JUSTIÇA NO CONTEXTO DEMOCRÁTICO}

A questão do acesso à justiça tem como ponto de apoio especialmente os conceitos de democracia e seus correlatos. Isso porque a democracia não é apenas um método de escolha de governantes (SCHUMPETER, 1983). Democracia significa uma forma de organizar a sociedade com o objetivo de garantir e expandir os direitos (O'DONNELL, 2004). Ou seja, a democracia envolve mudanças na sociedade, envolve ainda a adoção, pelos indivíduos que compõem um dado Estado, de um sistema de crenças, valores e atitudes em relação à cidadania (JELIN e HERSHBERG, 1996). Assim sendo, a cidadania, como correlata da democracia, pressupõe que os cidadãos possuem não apenas direitos mas, também responsabilidades e deveres, ${ }^{4}$ os quais devem se consolidar em um dado sistema de crenças, valores e atitudes para que a própria democracia possa institucionalizar-se (JELIN, 1996, p. 106).

De acordo com De La Paz (2004) a cidadania pode ser entendida como um status legal e uma identidade e, em sendo dessa forma, a cidadania possui uma dimensão bem objetiva, relacionada a direitos e deveres dos indivíduos diante do Estado.

Retomando a formulação original de TH Marshall (1967), a cidadania possui três dimensões fundamentais que se traduzem em três tipos de direito: os civis, os políticos e os sociais. Cada uma dessas três dimensões pode ser traduzida em um feixe de regras e instituições. Mesmo porque, como bem ressalta Roberts (2005), a democracia nada mais é que o somatório de regras e instituições que cultuam valores cidadãos. De forma esquemática essas três dimensões podem ser assim representadas, como mostra o QUADRO 2. 
Assim, se por um lado a cidadania implica que o Estado ofereça instituições substantivamente capazes de assegurar o provimento desses direitos, por outro a cidadania implica que os indivíduos sob seu governo sejam capazes de: (i) conhecer os direitos da cidadania, inclusive, no que diz respeito às responsabilidades que eles implicam; (ii) identificar no aparelho estatal quais são as instituições responsáveis pelo provimento de cada categoria de direitos; e (iii) exercer os seus deveres e direitos de forma legítima, de acordo com as regras postuladas pela democracia.

Nesses termos, a questão do acesso à justiça, como possibilidade de os cidadãos terem os seus conflitos resolvidos institucionalmente no âmbito do judiciário de forma célere e sem quaisquer distinções, liga-se à própria idéia de regras e instituições da cidadania civil. Em sendo dessa forma, para que os cidadãos possam exercer os seus direitos civis faz-se indispensável a existência de um judiciário amplamente permeável às questões que são levadas ao seu conhecimento.

$\mathrm{Na}$ medida em que a questão do acesso à justiça está diretamente ligada à democracia, esse debate apenas pode florescer no Brasil após a transição do autoritarismo (1964 a 1979) à democracia iniciada no início da década de 1980 e consolidada com a promulgação da Constituição Federal de 1988, que estabeleceu as principais regras da cidadania civil e as linhas mestras para funcionamento das instituições responsáveis por seu provimento.

Nesse cenário, Junqueira (1996) chama a atenção para o fato de que o tema acesso à justiça começou a despertar interesse nos pesquisadores brasileiros a partir de 1980. Contudo, esses não estavam interessados na forma como o Estado ampliava a sua permeabilidade às questões da cidadania civil, e sim na visão que os cidadãos tinham do judiciário e em que medida eles utilizavam a principal instituição da cidadania civil para resolver seus conflitos.

Essas primeiras abordagens eram baseadas em pesquisas de opinião sobre o assunto as quais denotavam que a população além de não confiar no judiciário para a solução de controvérsias (na medida em que este não era tão imparcial quanto esperado) ainda não recorria a ele para a solução de seus conflitos (preferindo, portanto, uma solução privada), dado o fato de ser extremamente moroso e pouco permeável a demandas dos cidadãos.

A pesquisa mais importante publicada na década de 1980, no entender de Junqueira (1996) é, sem sombra de dúvida, a realizada por Falcão (1981), acerca do acesso à justiça no Brasil. A partir dessa pesquisa, o autor constrói um texto que se transforma em referência obrigatória do campo. Partindo da idéia de democratização do Poder Judiciário, esse autor passa a afirmar que a questão do acesso à justiça deve a ser entendido como um mecanismo capaz de administrar o novo padrão de conflitualidade emergente no Brasil. Ainda no entendimento de Falcão (1981), a contribuição que o judiciário deveria propiciar ao processo de democratização que o País vivenciava naquela época era exatamente a criação de mecanismos alternativos 
para a solução desses novos conflitos. Ou seja, em detrimento de negar os conflitos do padrão emergente, o judiciário deveria ser capaz de reconhecê-los e tentar equacioná-los. Contudo, àquela época esse ainda não era o padrão de operação do sistema judicial brasileiro.

A ausência de pesquisas sobre esse tema no Brasil é importante de ser destacada porque, nos demais países - tanto da Europa Central como da América Latina -, a questão do acesso à justiça estava especialmente relacionada às atividades do Florence Project, coordenado por Mauro Capelletti e Bryant Garth com financiamento da Ford Foundation (Junqueira, 1996). No entanto, como o Brasil não participou do projeto e como a publicação desse texto, em português, apenas ocorreu em 1988, é a partir desse marco que se verifica a difusão das idéias de Cappelletti e Garth (1988) não apenas nos meios acadêmicos como também entre os legisladores e juristas brasileiros. Segundo esses autores, o acesso à justiça deveria ser entendido como um fenômeno que tem em sua ossatura três pilares de constituição: (i) a expansão da oferta de serviços jurídicos aos setores pobres da população;(ii) a incorporação dos interesses coletivos e difusos; e (iii) a contemplação de mecanismos alternativos de solução de litígios, tais como a justiça informal, a simplificação da lei e o desvio de casos de competência do sistema formal legal.

Os primeiros sinais dessa onda cappellettiana no Brasil podem ser verificados ao longo da década de 1990, quando o interesse dos acadêmicos brasileiros sobre o assunto cresceu substancialmente, especialmente após as reformas introduzidas com a publicação das leis relativas aos juizados especiais (ć́veis e criminais) e outras pequenas alterações, especialmente no Código de Processo Civil, que tinham como objetivo tornar o judiciário mais susceptível às demandas populares (CUNHA, 2001).

Vianna (1997) destaca que os grandes interesses acadêmicos na década de 1990 eram relativos a quem têm acesso certo ao Poder Judiciário entendido como tal não apenas quem recorre ao judiciário, mas, ainda quem compreende o funcionamento dessa instância e quem alcança uma decisão por parte deste. Daí por que a questão do acesso à justiça não pode ficar circunscrita aos aspectos quantitativos do número de processos distribuídos e julgados nos diversos tribunais brasileiros a cada ano (VER GRÁFICO 1), mas deve ainda procurar compreender em que medida a idéia de que os grandes interesses servem-se da arbitragem extrajudicial, enquanto a grande maioria dos cidadãos comuns continuam excluídos dessa instância se faz presente nesta realidade.

Essa distinção é importante de ser pontuada porque uma análise do acesso à justiça apenas segundo o número de ações iniciadas e encerradas anualmente pode levar a conclusões equivocadas sobre o acesso que a população em geral possui ao judiciário. Isso porque, analisando apenas esses dados, é possível verificar que tanto o número de ações distribuídas como o número de ações julgadas tem aumentado substancialmente nos últimos anos e, por conseguinte, poder-se-ia afirmar que esses dados 
indicam uma ampliação do acesso à justiça, já que mais pessoas estão iniciando processos e outras tantas estão obtendo o pronunciamento judicial.

Contudo, apesar de essa proposta ser tentadora, não é possível afirmar que o acesso ao judiciário, especialmente pelas camadas mais pobres da população, tem se ampliado nas últimas décadas. Isso porque esses quantitativos não fazem nenhuma referência às características de quem inicia ou quem obtém um pronunciamento judicial. Assim, a questão do número de processos distribuídos e julgados, apesar de relevante, esconde o problema da incorporação das massas sem direitos, ou socialmente prejudicadas, à cidadania, uma vez que esses números não são capazes de revelar quem tem e quem não tem acesso à justiça.

Como destacado por Boaventura de Souza Santos (1996), na medida em que a compreensão da problemática do acesso à justiça deve, necessariamente, contemplar as dimensões sociais que bloqueiam o alcance dos cidadãos à prestação jurisdicional, analisar apenas o número de processos distribuídos e julgados nos últimos anos nos diversos tribunais estaduais, apesar de relevante, não é suficiente para a análise da problemática.

Dessa forma, a discussão do acesso à justiça deve centrar seu foco na necessidade aumentar a proximidade do Judiciário com os setores de baixa renda, com as massas desprovidas de direitos, o que, na visão de Vianna (1997), significa a reordenação do sistema judicial, o qual deve perder uma parte de sua ordem racional-legal em favor da instituição de uma pedagogia ético-moral que viabilize o exercício da cidadania para setores da população que até o presente momento encontram-se excluídos do espaço público.

Ou seja, tendo em vista a própria definição de acesso à justiça com a qual estamos trabalhando e o cenário pontuado por Kant de Lima (2000), o fato de o judiciário operar no Brasil de forma excludente - em termos de sua morosidade, da compreensão das regras de funcionamento e ainda do que ocorre no seu interior faz com que apenas as classes dominantes tenham acesso amplo e irrestrito a essa instância. O que se percebe é que ampliação do acesso à Justiça apenas poderá ocorrer a partir da atualização do Poder Judiciário no que tange à alteração do seu cenário institucional. É a partir dessa perspectiva que a Emenda Constitucional 45 será analisada na seção subseqüente.

\section{Alterações introduzidas no sistema judicial PEla EMENDa CONSTITUCiONAL 45/04}

Esta seção se destina à análise, a partir da perspectiva de ampliação do acesso à justiça, das seguintes alterações constitucionais introduzidas pela EC 45/04: (i) razoável duração do processo; (ii) proporcionalidade entre o número de juízes na unidade jurisdicional e a efetiva demanda judicial e a respectiva população; (iii) funcionamento 
ininterrupto da atividade jurisdicional; (iv) distribuição imediata dos processos em todos os graus de jurisdição; e (v) instituição do Conselho Nacional de Justiça.

\section{I RAZOÁVEL DURAÇÃo do PROCESSO}

Conforme destacado por Sadek (2001), formalmente, desde a promulgação da Constituição de 1988 o Brasil pode ser classificado como um Estado de Direito e como uma democracia. Isso significa que, em tese, nenhuma lesão ou ameaça de lesão a direito pode ser excluída de apreciação pelo Poder Judiciário. No entanto, esse preceito legal nem sempre se traduz em realidade e, entre as razões apontadas para a ocorrência de tal fenômeno, tem-se o excesso de prazo despendido pelo sistema judicial no processamento e julgamento das demandas.

De acordo com Santos (1996), o tempo mais visível do sistema judicial é aquele que transcorre entre a ocorrência do conflito e a sua resolução pela via institucional. Ao processamento moroso são associados os sentimentos de impunidade e insegurança, e ao processamento ágil é atribuída a eficácia do sistema na pacificação dos conflitos sociais.

O tempo da justiça brasileira, formalmente, é o ordenado e definido por normas inscritas nos diversos códigos processuais, os quais regulam a cronologia da intervenção judicial e, por isso, deve ser conhecido e seguido pelos operadores do direito. Contudo, o que se percebe é que na realidade cotidiana dos tribunais esse tempo nem sempre é respeitado, transformando o sistema em algo moroso e, por isso, objeto de constantes críticas.

O tempo da justiça criminal tem sido amplamente estudado por sociólogos no que se refere especificamente ao tempo de processamento para o delito de homicídio doloso. Os resultados dessas pesquisas - sumarizados no QUADRO 3 -, apontam para o fato de que, independente do Estado da federação em análise, os tribunais despendem, no mínimo, duas vezes mais tempo do que o prescrito pelo Código de Processo Penal para julgamento de tais demandas.

Nesses termos, o que essas pesquisas parecem indicar é que há uma discrepância muito grande entre a norma e a sua aplicação na realidade da “vida como ela é”. Segundo Vargas (2004), pelos manuais de direito, o tempo prescrito pelo Código de Processo Penal tem por finalidade permitir a aplicação de um direito que proteja as garantias constitucionais e, na medida em que esse tempo não é respeitado, o próprio judiciário deveria ser processado por transgressão das normas constitucionais. O problema da morosidade, portanto, afeta não apenas a população como a imagem do judiciário e daí porque os estudos que investigam a visão dos juízes sobre a crise no judiciário tendem a apontar a falta de agilidade como um dos mais sérios problemas (SADEK et al., 2001). No que diz respeito às causas da morosidade, os magistrados tendem a enfatizar fatores sobre os quais não possuem responsabilidade, como o excesso de recursos e outras medidas disponíveis para os operadores, a carência de recursos materiais e o excesso de trabalho (CUNHA, 2001). 
Nesses termos, qualquer reforma que tenha como objetivo tornar a prestação judicial mais efetiva por intermédio da instituição de um prazo mais razoável para o processamento das demandas deve, necessariamente, alterar esses problemas, quais sejam: o excesso de recursos protelatórios existentes, a ausência de proporcionalidade entre juízes e habitantes das diversas regiões e a carência de recursos materiais.

Mas apenas mudar o texto da Constituição parece não resolver o problema, posto que, os próprios códigos de processo já existentes no Brasil prevêem um prazo bastante inferior ao que é realizado na prática dos tribunais. Assim, a questão da morosidade está muito mais relacionada à criação de uma instância externa que cobre dos operadores do direito o cumprimento dos prazos e que os puna em caso de descumprimento do que mudanças no texto constitucional.

Aliás, diversas pesquisas realizadas nos Estados Unidos sobre essa temática colocam que alterações no art. $6^{\mathrm{O}}$ de sua Constituição (que garante o direito ao "Speed Trial Act”), pela via do estabelecimento de um prazo máximo para a duração do processo não foram capazes de alterar o cenário de morosidade judicial vivenciado pelo país ao longo das décadas de 1970 e 1980. Ainda de acordo com a revisão dos estudos sobre essa temática, apenas a alteração das formas de condução do processo como um todo, e ainda a inserção da figura de um juiz corregedor que impedia que certos juízes demorassem mais do que o previsto com o processo em suas mãos, foi capaz de reduzir o tempo de duração dos processos (SIEGEL e SENNA, 2007).

Portanto, trata-se de uma falácia acreditar que apenas a inscrição do princípio da razoabilidade na Constituição pode suscitar transformações que impliquem a reorientação do arranjo organizacional existente no Poder Judiciário. Apenas a alteração dos constrangimentos sistêmicos pode, de fato, promover uma ampliação do acesso da população à justiça, por intermédio da celeridade dos pronunciamentos judiciais.

\subsection{Proporcionalidade entre o número de Juízes na Unidade Jurisdicional,}

\section{A EFETIVA DEMANDA JUDICIAL E A RESPECTIVA POPULAÇÃO}

As discussões acadêmicas a respeito dos gargalos do sistema judicial terminam por convergir para um mesmo argumento, o de que grande parte da morosidade da justiça deve-se ao número insuficiente de juízes. Ou seja, a carência de recursos humanos seria responsável pelo excesso de prazo despendido no processamento e julgamento das causas. Assim, a proposta de razoável duração do processo apenas se tornaria viável se o número de magistrados se conformasse em uma função linear da demanda judicial e da respectiva população. No entanto, esse argumento parece desvelar-se como falacioso.

De acordo com Pinheiro et al. (1999), no Brasil havia 5.164 juízes em 1990 - um juiz, em média, para cada 29.774 habitantes. Na Alemanha, a relação é de um juiz para 3.448 habitantes; na Itália, um para 7.692; e na França, um para 7.142. Ou seja, a proporcionalidade de juízes de fato é um problema a ser resolvido no cenário do judiciário. 
Recuperando os dados da pesquisa de Sadek et al. (2001) sobre o acesso a justiça, torna-se possível afirmar que, caso todos os 9.453 cargos de juiz previstos em lei estivessem preenchidos (informação relativa a 1998), o Brasil apresentaria um magistrado para cada 16.954 habitantes, um índice bem razoável para países em desenvolvimento, apesar de inferior aos apresentados por nações desenvolvidas como Alemanha, Itália e França. No entanto, em face da existência de cargos previstos mas não preenchidos, a relação se reduz a um juiz para cada 23.090 habitantes (VER TABELA 1).

Conforme informado pelos dados, o deficit de juízes em cada unidade da federação é bastante distinto. Há estados, como Sergipe, que não apresentam diferenças entre o número de juízes previstos e o provido, e há estados, como o Amazonas, em que essa diferença ultrapassa os 70\%. Nesses termos, o aumento do número de magistrados em alguns lugares pode, de fato, refletir em uma melhoria do acesso da população à justiça, já em outros essa medida não produzirá os efeitos desejados, já que ademais do aumento do quantitativo de operadores da justiça, os instrumentos que promovem a movimentação dessa continuam morosos e inadequados e, por isso, incapazes de efetivamente ampliar o acesso da população ao Poder Judiciário.

Outro dado relevante a ser analisado, quanto ao atual acesso à justiça, diz respeito aos indicadores de produtividade do sistema, ou seja, o número de processos distribuídos proporcionalmente ao número de juízes e o número de processos julgados por juízes. Comparando esses dois números, identifica-se a produção de cada magistrado e, por outro lado, quantos magistrados eram necessários no Brasil, em 1998, para que todas as causas que ingressassem a cada ano na justiça comum fossem julgadas nesse mesmo ínterim (VER TABELA 2).

Esses dados revelam que em 1998, cada juiz no Brasil julgava, em média, 705 processos enquanto deveria julgar 1.066 para que nenhuma causa distribuída naquele ano passasse ao seguinte sem decisão. Na hipótese de que todos os cargos previstos fossem providos, cada juiz deveria julgar 782 processos por ano, ou seja, cada juiz trabalharia apenas $10 \%$ a mais do que trabalha hoje para conseguir suprir toda a demanda.

Considerando as informações existentes no website da Secretaria de Reforma do Poder Judiciário (órgão do Ministério da Justiça), no ano de 2003, no Brasil possuía 13.660 (43\% a mais do que em 1998). ${ }^{5}$ Considerando ainda as informações do Conselho Nacional de Justiça, nesse mesmo ano, foram distribuídos 226.440 processos, os quais, somados aos pendentes, de anos anteriores (112.726), resultavam em 339.166 processos. Se fizermos uma razão do número de processos que deveriam ser julgados em 2003 com o número de juízes existentes naquele ano, chegaríamos à conclusão de que cada juiz deveria ter julgado 25 processos para que o ano seguinte não tivesse início com processos pendentes (atualmente, seguindo essa lógica, cada juiz julgava, em 2003, em média, 13 processos). 
No entanto, a problemática da ausência de proporcionalidade entre o número de juízes na unidade jurisdicional e a efetiva demanda judicial é distinta conforme a unidade da federação. Isso significa que apenas um estudo sistemático desse problema pode indicar qual seria a quantidade adequada para compatibilizar o número de magistrados com o tamanho da população nos diversos Estados e, assim, fixar, em cada um deles, qual seria o índice de produtividade de cada profissional para sanar o problema. Em 1998, isso significava que cada juiz que ingressasse deveria julgar 997 causas para que o problema dos processos não julgados naquele ano fosse resolvido.

É importante destacar que essa redução substancial existente entre os números de processos e de juízes existentes no período compreendido entre 1998 e 2003 deve-se ao fato de que o número de juízes cresceu em proporções bastante superiores ao número de processos distribuídos.

Nestes termos, a questão da proporcionalidade entre o número de juízes, a população e a efetiva demanda parece não estar relacionada tanto à ampliação do número de juízes existentes mas, ao perfil desses julgadores. Conforme destacado por Carvalho (1997), o bom juiz é aquele que acompanha e vive seu tempo, que compreende que a parcela de autonomia do Poder a que pertence (já que nenhuma autonomia é absoluta na democracia), que reconhece as deficiências e mazelas existentes em sua instituição e busca superá-las em benefício da pacificação de conflitos e, por fim, é aquele que interpreta a lei no sentido de aproximá-la dos processos sociais substantivos, influindo, assim, na mudança social. Apenas esse juiz pode ser entendido como um agente de preservação e garantia dos direitos individuais e coletivos.

Vianna (1997) também desvela essa problemática ao afirmar que não há democratização do Judiciário sem a presença de uma atitude do juiz compatível com as exigências que dela derivam. Se o perfil de juiz como "boca inanimada da lei" é claramente descompassado dos métodos e das formas de acesso democratizado, a magistratura como novo clero a pastorear o seu rebanho não corresponde ao objetivo de fazer do acesso à Justiça um lugar de educação para a cidadania.

Assim, é possível afirmar que a EC 45/04 seria mais eficiente se estabelecesse uma produtividade mínima para cada juiz e ainda se acompanhasse como cada um realiza ou não sua produtividade e, por fim, se punisse aqueles que não seguissem esses parâmetros. Em parte, essas atividades são atribuições do Conselho Nacional de Justiça mas ainda não se encontram verificadas na realidade do funcionamento dessa instância.

Por fim, como bem destaca Hertel (2005), a eficácia de medidas dessa natureza dependerá de uma boa administração dos dados por parte dos órgãos competentes, em especial por parte do Conselho Nacional de Justiça, o qual, nos termos do art. 103-B, §. 4, inc. VII, da CF/88, tem, dentre outras competências, a de apresentar relatório anual sobre a situação do Judiciário no País, propondo as providências que entenderem cabíveis. 


\subsection{FUNCIONAMENTO ININTERRUPTO DA ATIVIDADE JURISDICIONAL}

A partir da EC/45, o art. 93 da CF/88 passou a vigorar com a seguinte redação: “[...] a atividade jurisdicional será ininterrupta, sendo vedado férias coletivas nos juízos e tribunais de segundo grau, funcionando, nos dias em que não houver expediente forense normal, juízes em plantão permanente".

A motivação dessa reforma diz respeito ao fato de que todos os dias milhares de ações ingressam nas distintas instâncias do Poder Judiciário. No entanto, esse número poderia ser mais elevado, caso a atividade jurisdicional não apresentasse recessos. Como a maioria dos conflitos tende a ocorrer durante os finais de semana, feriados e férias, quando o tribunal de justiça também está fechado, é bem provável que, quando retomada a atividade jurisdicional, as partes já tenham resolvido o seu conflito na arena privada.

Essa proposta da EC/45 é sem dúvida um ponto polêmico. Na sistemática anterior à EC/45, apenas as causas urgentes, como as que implicam prestações alimentícias, são despachadas nos períodos de férias e recesso forense enquanto as demais devem aguardar a retomada das atividades para o seu prosseguimento. No período de férias e recessos, em que o tribunal está fechado, ficam suspensos os prazos processuais e também a publicação de acórdãos, sentenças e outras decisões no Diário da Justiça, bem como intimações de partes e advogados na primeira e segunda instância -, exceto em relação a matérias urgentes e inadiáveis. Ocorre que essa demora na materialização da prestação jurisdicional acaba potencializando conflitos na sociedade. Assim, à medida que pequenas demandas deixam de ser prontamente atendidas, abre-se espaço para que elas retornem aos tribunais na forma de conflitos mais graves.

Neste sentido, essa mudança se faz indispensável no sentido de melhorar a prestação jurisdicional e ainda reduzir a sua morosidade. No entanto, essa inovação institucional deve ser analisada com cautela, uma vez que a simples previsão constitucional não implica sua implementação imediata. É preciso regulamentar, em que termos a prestação jurisdicional deverá ocorrer nos períodos de férias e recessos forenses, pois, caso contrário, corre-se o risco de continuidade do regime de plantão hoje verificado na maioria das instâncias do Poder Judiciário, como forma de caracterizar o funcionamento ininterrupto da atividade jurisdicional.

Cumpre destacar que essa medida somente tem aplicação aos tribunais de segundo grau. No que concerne aos Tribunais Superiores, dentre eles o STF e o STJ, não se veda a interrupção da atividade no período de férias. Nesse particular, o constituinte derivado foi tímido e perdeu ótima oportunidade para adotar mais uma medida de incremento da celeridade da atividade jurisdicional (HERTEL, 2005). Ou seja, ainda que a Emenda Constitucional pudesse transformar o atual cenário de funcionamento do sistema, ela apenas o faria pela metade, dada à sua própria restrição em termos de escopo. 


\subsection{DistribuiçÃO IMEDiATA DOS PROCESSOS EM TODOS OS GRAUS DE JURISDIÇÃo}

A distribuição do processo é, sem dúvida, uma das problemáticas que mais carece de compreensão por parte dos leigos em matéria judicial. Isso porque ela diferencia os momentos em que o indivíduo se dirige à Justiça do momento em que essa estrutura institucional efetivamente começa a se movimentar em torno de sua causa.

Essa diacronia refere-se ao fato de que o protocolo de uma ação em qualquer instância judicial não significa o conhecimento do conflito, o qual só ocorre quando outras ações desobstruem o caminho para ingresso de uma nova. É como uma fila: cada novo integrante deve esperar a sua vez de chegar até o balcão de informações, o qual lhe direcionará a uma nova fila, esta de atendimento. A primeira fila pode ser equiparada ao protocolo da causa nos tribunais e a segunda a sua distribuição entre os juízes, o qual passa a ficar responsável pelo conhecimento e pacificação do conflito.

Ocorre que o tempo entre esses dois momentos tende a ser excessivo e motivo de inúmeras controvérsias. Chega-se ao absurdo de algumas causas serem distribuídas quando um dos envolvidos já faleceu, anos depois, ou ainda, quando o conflito que as suscitou nem existe mais. Nesse sentido, a reforma proposta pela EC 45/04 tem como intuito tornar esses dois atos simultâneos. Retomando o exemplo anterior, é como se o cidadão chegasse ao local e fosse prontamente atendido, sem ter de passar por nenhuma das duas filas.

Apenas para se ter uma idéia da dimensão do problema, de acordo com Hertel (2005), no Estado de São Paulo, o Tribunal de Justiça demorava aproximadamente quatro anos apenas para distribuir o recurso ao Tribunal de Segunda Instância. Com a nova previsão no texto constitucional, todos os recursos que estiverem "represados" deverão ser imediatamente distribuídos.

De qualquer modo, como bem destaca Hertel (2005) essa alteração não traz efeitos pragmáticos de relevo. É que o processo será imediatamente distribuído, mas demorará mais a ser julgado. Troca-se, na verdade, apenas faticamente o lugar dos documentos: antes da alteração, eles ficavam na sala do distribuidor; após a alteração da EC 45, eles ficam na Secretaria do órgão competente ou no Gabinete do magistrado competente.

Portanto, a medida, por si só, é ineficaz. Melhor seria dotar o Poder Judiciário de estrutura apta a realizar julgamentos com celeridade, o que mais uma vez aponta para a importância do Conselho Nacional de Justiça nesse cenário. Ou seja, se a simples distribuição imediata das causas não for acompanhada da expansão da capacidade institucional do judiciário em julgá-las, a EC/45 não ampliará de fato o acesso à justiça, uma vez que os processos permanecerão imóveis nos órgãos julgadores.

\subsection{Instituição do Conselho Nacional de Justiça}

Sem dúvida, uma das reformas mais importantes introduzidas pela Emenda Constitucional 45 foi a criação do Conselho Nacional de Justiça como organismo responsável pelo exercício do controle externo do Poder Judiciário (UCHOA, 2006). 
Como bem destaca o breve relato histórico sobre a constituição do sistema judicial brasileiro (seção 2), em razão dos resquícios da colonização portuguesa, o judiciário brasileiro sempre foi caracterizado como excludente e pouco permeável a demandas universais, que terminavam se traduzindo em um acesso diferencial à justiça. Nesse sentido, faz-se indispensável a criação de um sistema de freios e contrafreios que permitisse que o acesso diferencial à justiça deixasse de ser uma prática dos tribunais. No sentido de corrigir essa ausência de justiça para a própria justiça, a Emenda Constitucional 45 instituiu o Conselho Nacional de Justiça. ${ }^{6}$

Segundo a redação dada pela EC 45 ao $\S 4^{\mathrm{O}}$, do art. 103-B, da Constituição Federal, compete ao Conselho Nacional de Justiça a realização das seguintes atividades: (i) zelar pela autonomia do Poder Judiciário e pelo cumprimento do Estatuto da Magistratura; (ii) zelar pela observância do art. $37 \mathrm{da} \mathrm{CF} / 88 ;^{7}$ (iii) reconhecer das reclamações contra membros ou órgãos do Judiciário, inclusive contra serviços auxiliares, serventias e órgãos prestadores de serviços notariais, sem prejuízo da competência disciplinar e correicional dos tribunais, podendo avocar processos disciplinares em curso e determinar remoção, disponibilidade ou aposentadoria com subsídios ou proventos proporcionais ao tempo de serviço e aplicar outras sanções administrativas, assegurada ampla defesa; (iv) representar ao Ministério Público no caso de crime contra a Administração Pública ou abuso de autoridade; (v) rever, de ofício ou mediante provocação, processos disciplinares de membros do Judiciário julgados a menos de um ano; (vi) elaborar relatórios semestrais acerca de estatísticas sobre processos e sentenças prolatadas nos mais diferentes órgãos do Judiciário do país; e (vii) elaborar relatórios anuais propondo providências que julgar necessárias à melhoria da situação e das atividades do Poder Judiciário.

$\mathrm{Na}$ medida em que essas atividades são extremamente complexas e interferem diretamente na atividade dos juízes, este órgão é composto por membros ínsitos e externos à estrutura judiciária, garantindo que a aplicação de sanção disciplinar, quando for o caso, seja completamente imparcial. Atualmente, o Conselho Nacional de Justiça (CNJ), é presidido pelo Ministro Gilmar Mendes, indicado pelo Supremo Tribunal Federal, e possui 15 conselheiros, aprovados pelo Senado e então nomeados como tal pelo Presidente da República.

A criação desse órgão foi colocada como grande “inovação" porque os setores dominantes do Judiciário sempre se opuseram à idéia da criação de um órgão de controle de suas atividades. Um órgão que não apenas estabelecesse metas a serem cumpridas como ainda punisse os membros de tal poder pelo descumprimento destas. Nesses termos, a possibilidade de o judiciário contar com um organismo que possa cobrar dos juízes e demais servidores um desempenho mais condizente com as necessidades da população é, de fato, um grande avanço no que diz respeito à transparência da prestação jurisdicional.

Em razão dessa tradição de pouca transparência e controle sob suas ações, os próprios integrantes do judiciário impetraram diversas ações discutindo a constitucionalidade do CNJ. Fato é que esse Conselho apenas foi instalado no âmbito da 
estrutura judicial brasileira ${ }^{8}$ em 14.06.2005. Desde então, ele realizou 22 sessões ordinárias e dez sessões extraordinárias. De acordo com o relatório institucional do CNJ (2008), essas seções foram destinadas à análise e tentativa de sentença dos processos recebidos em 2006 (2.575 processos recebidos e 2.060 processos julgados) e 2007 ( 3.771 processos recebidos e 3.597 processos julgados).

É importante salientar que nesse período, a maioria dos processos recebidos pelo CNJ se referiam à corregedoria e tinham como tema o pedido de providências pelo excesso de prazo dos tribunais estaduais no processamento e julgamento das demandas apresentadas (CNJ, 2008).

Além desses processos, cujo processamento é de competência da corregedoria do $\mathrm{CNJ}$, o órgão realizou várias atividades destinadas a melhorar o acompanhamento e a prestação de contas dos diversos tribunais judiciais. As ações propostas pelo CNJ, desde a sua instituição, e o estado que elas se encontram na atualidade estão resumidas no QUADRO 3.

A análise das atividades desenvolvidas pelo CNJ desde a sua constituição até a atualidade parece denotar a preocupação deste em não apenas processar os processos iniciados especialmente por excesso de prazo nos tribunais mas, ainda, instituir sistemas que permitam um acompanhamento mais minucioso do que o que ocorre em cada um dos tribunais. Esses sistemas, por sua vez, são indispensáveis para que o CNJ possa desenvolver ações pontuais destinadas a reduzir a morosidade processual, tornar os procedimentos judiciais menos complexos (pela ênfase nos procedimentos alternativos de justiça - como a conciliação), e ainda aumentar a transparência na prestação jurisdicional. Se esses objetivos serão ou não alcançados, apenas o tempo dirá.

\section{CONSIDERAÇÕES FINAIS}

O objetivo deste artigo foi investigar em que medida algumas das transformações institucionais previstas pela Emenda Constitucional 45 podem ampliar o acesso da população à justiça; dentre as mudanças institucionais previstas foram analisadas: (i) razoável duração do processo; (ii) proporcionalidade entre o número de juízes na unidade jurisdicional e a efetiva demanda judicial; (iii) distribuição imediata dos processos em todos os graus de jurisdição; (iv) funcionamento ininterrupto da atividade jurisdicional; e (v) criação do Conselho Nacional de Justiça

Essas mudanças institucionais foram escolhidas entre o conjunto de alterações previstas pela EC 45 porque o fato de problemas como excesso de tempo no processamento das causas, carência de um número de juízes compatível com o número de habitantes de cada circunscrição, ausência de correspondência entre o momento do fato e o seu ingresso no sistema judicial, bem como entre este e o fim do processamento efetivo da demanda; além do fato de o judiciário ser pouco permeável à prestação de contas e a punição de transgressão serem problemas constantemente apontados pela 
literatura especializada como principais dificuldades encontradas pela população no que diz respeito ao acesso à justiça e, por conseguinte, o descrédito nessa instituição.

A análise das transformações previstas pela EC 45 revelou que algumas das questões apontadas poderiam ser resolvidas a partir apenas do cumprimento da legislação infraconstitucional em detrimento de sua inserção no âmbito do texto constitucional. Isso porque essas disposições já se encontram previstas em diversas outras legislações sem, contudo, serem efetivadas na realidade cotidiana dos tribunais. São alterações previstas nesse diploma legal que se encaixam nesta percepção: (i) razoável duração do processo; (ii) proporcionalidade entre o número de juízes na unidade jurisdicional e a efetiva demanda judicial; (iii) distribuição imediata dos processos em todos os graus de jurisdição; e (iv) funcionamento ininterrupto da atividade jurisdicional.

Portanto, de acordo com essa constatação, a criação do Conselho Nacional de Justiça pode ser entendida como uma exceção a esse fenômeno na medida em que esse órgão se constitui uma alteração institucional de extrema importância no que diz respeito ao aumento da transparência dos atos judiciais, aumento da efetividade do sistema de prestação de contas dos tribunais estaduais, aumento da possibilidade de punição dos juízes que agem em desacordo com a sua missão institucional (accountability) e, por fim, aumento da eficiência do sistema de pesos e contrapesos indispensável ao bom funcionamento do judiciário.

Ao contrário das demais alterações analisadas, a criação do Conselho Nacional de Justiça, em funcionamento desde 2005, aponta para a importância de se alterar o cenário institucional de tal maneira a garantir a existência de um órgão capaz de cobrar dos tribunais estaduais as demais mudanças previstas na EC 45, mas que já existiam na legislação infraconstitucional. Isso porque, se tais dispositivos não têm funcionado na prática, uma das razões para tanto poderia ser a ausência de fiscalização contínua sobre os responsáveis pela implementação de tais regras e, ainda, a punição de quem violou esses dispositivos que antes eram apenas infraconstitucionais e agora integram o próprio texto da $\mathrm{CF} / 88$.

Apenas a partir do efetivo funcionamento do CNJ é que será possível avaliar a efetividade de tais disposições para além de sua simples elevação ao texto constitucional. Até o momento, os trabalhos já realizados por esse órgão apontam para uma grande preocupação com a efetividade do tempo de duração dos processos, o que por si só já apresenta um avanço dessa legislação, confirmando a importância da criação de instituições mais especializadas para o exercício da função de accountability no âmbito do judiciário. Com o aumento do escopo de atuação desse órgão espera-se que as conseqüências deletérias de problemas como: excessiva duração do processo, complexidade dos procedimentos judiciais, e falta de transparência da prestação jurisprudencial possam ser, finalmente, minorados permitindo, por conseguinte, a ampliação do acesso à justiça no Brasil. 


\section{NOTAS}

1 É importante destacar que a Emenda Constitucional 45 introduz alterações muito mais amplas do que as cinco destacadas no Quadro 1. No entanto, elas foram escolhidas para análise na medida em que interferem diretamente na estrutura organizacional da justiça, procurando dotá-la, por um lado, de maior capacidade operacional e, por outro, de maior controle institucional sobre seus próprios atos.

2 De acordo com o art. 3o da referida lei, esses juizados possuem competência na área cível para conciliação, processo e julgamento das causas cíveis de menor complexidade, assim consideradas: as causas cujo valor não exceda a 40 vezes o salário mínimo (essa competência foi posteriormente ampliada para 60 salários mínimos pela Lei 10.444, de 07.05.2002); as enumeradas no art. 275, inc. II, do Código de Processo Civil; as relativas a despejo para uso próprio; as ações possessórias sobre bens imóveis de valor não excedente ao fixado no inc. I desse artigo. Esses juizados também sofreram alterações em sua competência, posto que a partir do ano de 1999 passaram a admitir as microempresas como autoras (art. 38, da Lei 9.841/99).

No que se refere à sua competência, o art. 61 da Lei n. $9.099 / 95$ estabeleceu que esses [juizados] possuem competência para o processamento das infrações de menor potencial ofensivo, quais sejam: todas as contravenções penais (previstas ou não no Decreto-lei n. 3.688/41), e os crimes a que a lei comine pena máxima não superior a dois anos de prisão (a partir da alteração inserida pela lei 10.259/01), desde que tais crimes não se sujeitem a procedimento especial.

Por fim, cumpre destacar que o art. 275, inc. II, do CPP estabelece que será de competência dos juizados especiais cíveis o processamento das seguintes causas (qualquer que seja o valor): arrendamento rural e de parceria agrícola; cobrança ao condômino de quaisquer quantias devidas ao condomínio; ressarcimento por danos em prédio urbano ou rústico; ressarcimento por danos causados em acidente de veículo de via terrestre; de cobrança de seguro, relativamente aos danos causados em acidente de veículo, ressalvados os casos de processo de execução; de cobrança de honorários dos profissionais liberais, ressalvado o disposto em legislação especial e demais casos previstos em lei.

3 De acordo com Gomes e Bianchini (2006), o processamento de tais instâncias é diferenciado do processamento do Jecrim porque, nesses casos, não cabe transação penal nem suspensão condicional do processo, nem composição civil dos danos extintiva de punibilidade, não se lavra termo circunstanciado, deve ser instaurado inquérito policial, a denúncia deverá vir por escrito, o procedimento será o previsto no Código de Processo Penal e, em se tratando de lesão corporal leve, a ação penal será de iniciativa pública incondicionada.

4 De acordo com Jelin (1996, p. 106), o próprio Marshall, em sua formulação clássica sobre a cidadania, pontua os deveres que a concessão de direitos traz em sua ossatura. Contudo, no entender da autora, Marshall negligencia a discussão de tais deveres e, exatamente por isso, não devemos fazer o mesmo. Assim, se os direitos da cidadania são colocados quase que de forma cogente aos indivíduos que residem em países democráticos, os deveres que essa cidadania implica também devem ser entendidos como algo irrefutável.

5 Na Tabela 2 não foram usados os dados de 2003 porque o Ministério da Justiça apenas divulgou o número total de juízes e não o número total por Estado da Federação.

6 Como bem destaca Uchoa (2006), antes do Conselho Nacional de Justiça - CNJ, o Judiciário submetia o rigor de seus atos administrativos aos Tribunais de Contas. Contudo, é público e notório que, na prática, tais fiscalizações são meramente opinativas. Além disso, não são hábeis a acompanhar a temporalidade, o ritmo, dos atos praticados. Por outro lado, os tribunais também possuem as suas próprias corregedorias, que por se situarem no âmbito dos tribunais, acabam funcionando como mero órgão figurativo, ficando aqueles livres de quaisquer fiscalizações.

7 Leia-se, legalidade, impessoalidade, moralidade, publicidade e eficiência dos atos administrativos.

8 Isso porque a instalação do referido conselho foi objeto de diversas liminares que discutiam em que medida a existência de um orgão como este poderia ferir a idéia de soberania dos veredictos do poder judiciário. Nestes termos, apenas após encerrado o julgamento de tais liminares é que o Conselho Nacional de Justiça pôde ser finalmente instalado. 


\section{REFERÊNCIAS BIBLIOGRÁFICAS}

ALMEIDA JÚNIOR, João M. O processo criminal brasileiro. Rio de Janeiro: Tipografia Baptista de Souza, 1920. AZEVEDO, Rodrigo Ghiringhelli. O paradigma emergente em seu labirinto: notas para o aperfeiçoamento dos Juizados Especiais Criminais. Porto Alegre, 2004. (mimeo)

BATITUCCI, Eduardo C.; CRUZ, M. V. G.; SILVA, Breno I. Fluxo do Crime de Homicídio no Sistema de Justiça Criminal de Minas Gerais. In: $30^{\circ}$ Encontro da Associação Nacional de Pós Graduação e Pesquisa em Ciências Sociais - Anpocs, 2006, Caxambu. Anais do 30 Anpocs. São Paulo: Anpocs, 2006.

BRETAS, Marcos Luiz. A guerra das ruas: povo e polícia na cidade do Rio de Janeiro. Rio de Janeiro: Arquivo Nacional, 1997

CARVALHO, Luiz Fernando R. Democracia e Acesso à Justiça. In: Iuperj. Seminários Friedrich Naumann. IUPERJ, n. 5, 1997. p. 5-16.

CNJ. Relatório de Prestação de Contas das Atividades Realizadas no Ano de 2007. Brasília: Conselho Nacional de Justiça, 2008.

CUNHA, Luciana G. S. Juizado Especial: ampliação do acesso à justiça? In: SADEK, Maria Tereza. Acesso à justiça. São Paulo: Fundação Konrad Adenauer, 2001. p. 43-73.

DaMATTA, Roberto. Carnavais, malandros e heróis. Rio de Janeiro: Zahar, 1979.

DE LA PAZ, Gabriel. Citizenship Identity and Social Inequality. In: Instituto Federal Electoral San Diego: Center for Civic Education, Califórnia, 2004.

FALCÃO, Joaquim. Cultura jurídica e democracia: a favor da democratização do Judiciário. In: LAMOUNIER, Bolivar et al. Direito, cidadania e participação. São Paulo: Tao, 1981.

FAORO, Raymundo. Os donos do poder: formação do patronato político Brasileiro. Porto Alegre e São Paulo: Editora Globo e Editora Universidade de São Paulo, 1994.

FLORY, Thomas. Judge and jury in imperial Brazil 1808-1871. Texas: University of Texas Press, 1981.

FONTANA, Milton. A lei 10.259/01 e a competência dos juizados especiais criminais estaduais . Jus

Navigandi, Teresina, ano 6, n. 56, abr. 2002. Disponível em:

$<$ http: / /jus2.uol.com.br/doutrina/ texto.asp?id=2898>.

FOUCAULT, Michel. A verdade e as formas jurídicas. Rio de Janeiro: NAU Editora, 2003.

FREYRE, Gilberto. Casa grande e senzala. São Paulo: Global, 2004.

GOMES, Luiz Flávio; BIANCHINI, Alice. Aspectos criminais da Lei de Violência contra a Mulher. Teresina: Jus Navigandi, ano 10, n. 1169, 13 set. 2006. Disponível em:

<http: / /jus2.uol.com.br/doutrina/ texto.asp?id=8916>.

HERTEL, Daniel Roberto. Aspectos processuais da Emenda Constitucional n. 45 . Jus Navigandi, Teresina, ano 9, n. 783, 25 ago. 2005. Disponível em: <http://jus2.uol.com.br/doutrina/texto.asp?id=7192>.

HOLANDA, Sérgio Buarque. Raízes do Brasil. São Paulo: Companhia das Letras, 2004.

JELIN, Elizabeth; HERSHBERG, Eric. Human Rights and the construction of democracy. In: JELIN, Elizabeth e HERSHBERG, Eric (Org). Constructing Democracy: Human Rights, Citizenship and Society in Latin America. Westview Press, 1996.

Citizenship revisited: solidarity, responsibility and rights. In:

Human Rights, Citizenship and Society in Latin America. Westview Press, 1996.

JUNQUEIRA, Eliane B. Acesso à Justiça: um olhar retrospectivo. In: Revista Estudos Históricos, n. 18, 1996.

KANT DE LIMA, Roberto. Carnavais, malandros e heróis: o dilema brasileiro do espaço público. In: GOMES, Laura Graziela; BARBOSA, Lívia; DRUMOND, José Augusto. O Brasil não é para principiantes: carnavais, malandros e heróis 20 anos depois. Rio de Janeiro: FGV, 2000.

KANT de LIMA, Roberto. Cultura jurídica e práticas policiais: tradição inquisitorial. In: Revista Brasileira de Ciências Sociais. Rio de Janeiro, vol. 4, n. 10, jun. 1989, p. 65-84.

Polícia e exclusão na cultura judiciária. In: Tempo Social. Revista de Sociologia da Universidade de

São Paulo, vol 1, n. 9, mai 1997, p. 169-183.

KANT DE LIMA, Roberto; AMORIM, Maria Stella; BURGOS, Marcelo. A violência doméstica nos juizados especiais criminais brasileiros: desafios para o direito e para os tribunais brasileiros. Niterói, 2004. (mimeo). LETTERIELLO, Rêmolo. O perigo da ampliação da competência dos Juizados Especiais Cíveis . Teresina: Jus Navigandi, ano 9, n. 630, 30 mar. 2005. Disponível em:

<http://jus2.uol.com.br/doutrina/texto.asp?id=6546>.

MARSHALl, TH. Citizenship and Social Class. In: MARSHALl, T. H. Class, Citizenship and Social Development. Nova York: Garden City, 1967.

MARTINS, Humberto F. A ética do patrimonialismo e a modernização da administração pública brasileira. In: MOTTA, Fernandes Prestes (Org.). Cultura organizacional e cotidiano nas organizações brasileiras. São Paulo: Atlas, 1996. 
O’DONNELL, Guillermo. Notas sobre la Democracia en América Latina. Informe La Democracia en América Latina - Anexo 2: El Debate Conceptual sobre la Democracia en América Latina. 2004. Disponível em: $<$ http://democracia.undp.org $>$.

. Ilusiones sobre la consolidación. In: Nueva Sociedad, n. 144, jul./ago. 1996, p 70-89.

OLIVEIRA, Eduardo R. A idéia de Império e a fundação da Monarquia Constitucional no Brasil (PortugalBrasil, 1772-1824). In: Tempo, Rio de Janeiro, n. 18, mar. 2005, p. 43-63.

PAIXÃO, Antônio Luis. Notas sobre a organização policial numa área metropolitana. Dados, v. 25, 1982.

PINHEIRO, Paulo Sérgio (Coord. NEV-USP). Continuidade autoritária e construção da democracia. Relatório final. São Paulo: Fapesp/CNPq e Fundação Ford, 1999.

PRADO JÚNIOR, Caio. Formação do Brasil contemporâneo. São Paulo: Brasiliense, 1994.

ROBERTS, Bryan R. A dimensão social da cidadania. In: Revista Brasileira de Ciências Sociais, n. 33, São Paulo, 1997. . Citizenship, Rights and Social Policy. In: WOOD, Charles e ROBERTS, Brian (Org). Rethinking

Development in Latin America. Pensilvânia: Pennsylvania State University Press, 2005.

RUSCHEL, Aírton José. Análise do tempo dos Processos Penais de homicídio no Fórum de Justiça de

Florianópolis, julgados em 2004. Dissertação de Mestrado apresentada à Universidade Federal de Santa Catarina, 2006.

SADEK, Maria Tereza. Acesso à justiça. São Paulo: Fundação Konrad Adenauer, 2001.

. Maria Tereza; LIMA, Fernão D.; ARAÚJO, José Renato C. O judiciário e a prestação de justiça. In:

SADEK, Maria Tereza. Acesso à justiça. São Paulo: Fundação Konrad Adenauer, 2001, p. 13-41.

SANTOS, Boaventura de Souza. Os tribunais na sociedade contemporânea. In Revista Brasileira de Ciência Sociais, n. 30, 1996, p. 29-65.

SAPORI, Luís Flávio. A administração da Justiça Criminal numa área metropolitana. In: Revista Brasileira de Ciências Sociais, n. 29, out. 1995, p. 143-156.

SCHUMPETER, Joseph. Capitalismo, socialismo e democracia. São Paulo: EDUSP, 1983.

SCHWARTZ, Stuart B. Burocracia e sociedade no Brasil colonial. São Paulo: Perspectiva, 1979.

SHIRLEY, R. W. Antropologia jurídica. São Paulo: Saraiva, 1987.

SIEGEL, Larry; SENNA, Joseph. Essentials of criminal justice. Thompson, 2007.

UCHÔA, Marcelo R. O poder judiciário à luz da reforma da EC 45/04. Dissertação de Mestrado em Direito Constitucional apresentada à Universidade Federal de Fortaleza, 2006.

VARGAS, Joana D.; RIBEIRO, Ludmila M. L.; BLAVATSKY, Ismênia. Metodologia de tratamento do tempo e da morosidade processual na justiça Criminal. Relatório final de concurso. Brasília/DF: Secretaria Nacional de Segurança Pública, SENASP, Ministério da Justiça, 2006.

VARGAS, Joana D. Estupro: que justiça? Tese de doutorado. Rio de Janeiro: IupeRJ, 2004.

VIANNA, Luís Werneck. Democracia e acesso à justiça. In: Seminários Friedrich Naumann. Iuperj, n. 5, 1997, p. 17-23. . Luís W.; BURGOS, Marcelo B. Entre Princípios e Regras: cinco estudos de caso de Ação Civil

Pública. Rio de Janeiro: Cadernos do Centro de Estudos de Direito e Sociedade, Cedes, Iuperj, n. 1, 2005.

. Luís W.; CARVAlho, Maria Alice R.; MELO, Manuel P. C.; BURGOS, Marcelo B. A judicialização

da política e das relações sociais no Brasil. Rio de Janeiro: Ed. Revan, 1999.

WATANABE, Kazuo. Novas atribuições do Judiciário: necessidade de sua percepção e reformulação da mentalidade. In: Revista Escola Paulista da Magistratura, I, n. 1, set./dez. 1996. 
ANEXO - QUADROS, GRÁFICOS E TABELAS

\section{QUADRO I}

Problemas que dificultam o acesso à justiça no cenário brasileiro, e institutos criados pela Emenda Constitucional 45 (EC-45) para a sua resolução

\begin{tabular}{|l|l|}
\hline $\begin{array}{l}\text { PROBLEMAS QUE DIFICULTAM } \\
\text { O ACESSO À JUSTIÇA }\end{array}$ & $\begin{array}{l}\text { INSTITUTO DA EC } 45 \\
\text { QUE PROCURA RESOLVÊ-LOS }\end{array}$ \\
\hline EXCESSIVA DURAÇÃO DO PROCESSO & $\begin{array}{l}\text { RAZOÁVEL DURAÇÃO DO PROCESSO; } \\
\text { PROPORCIONALIDADE ENTRE O NÚMERO DE } \\
\text { JUÍZES NA UNIDADE JURISDICIONAL E A EFETIVA } \\
\text { DEMANDA JUDICIAL; }\end{array}$ \\
\hline COMPLEXIDADE DOS PROCEDIMENTOS JUDICIAIS & $\begin{array}{l}\text { DISTRIBUIÇÃO IMEDIATA DOS PROCESSOS EM } \\
\text { TODOS OS GRAUS DE JURISDICCÃO; } \\
\text { FUNCIONAMENTO ININTERRUPTO DA } \\
\text { ATIVIDADE JURISDICIONAL. }\end{array}$ \\
\hline $\begin{array}{l}\text { FALTA DE TRANSPARÊNCIA DA } \\
\text { PRESTAÇÃO JURISPRUDENCIAL }\end{array}$ & CRIAÇÃO DO CONSELHO NACIONAL DE JUSTIÇA \\
\hline
\end{tabular}

\section{QUADRO 2}

Elementos da cidadania, de acordo com a definição disseminada por Marshall e as instituições democráticas a ela associadas

\begin{tabular}{|c|c|c|}
\hline ELEMENTOS DA CIDADANIA & DEFINIÇÃO & $\begin{array}{l}\text { INSTITUIÇÕES } \\
\text { DEMOCRÁTICAS } \\
\text { ASSOCIADAS A } \\
\text { ESTE ELEMENTO }\end{array}$ \\
\hline DIREITOS CIVIS & 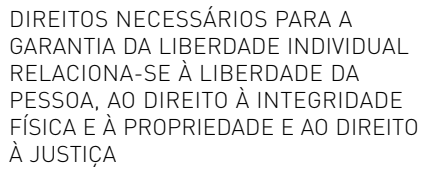 & TRIBUNAIS DE JUSTIÇA \\
\hline DIREITOS POLÍTICOS & $\begin{array}{l}\text { DIREITOS A PARTICIPAR DO EXERCÍCIO } \\
\text { DO PODER POLIITICO, COMO UM } \\
\text { INDIVÍDUO INVESTIDO DE AUTORIDADE } \\
\text { POLIITICA OU COMO O ELEITOR DE } \\
\text { TAIS AUTORIDADES }\end{array}$ & $\begin{array}{l}\text { CONGRESSO NACIONAL } \\
\text { PARTIDOS POLÍTICOS }\end{array}$ \\
\hline DIREITOS SOCIAIS & $\begin{array}{l}\text { DIREITO A BEM-ESTAR ECONÔMICO } \\
\text { E SOBREVIVÊNCIA MATERIAL }\end{array}$ & $\begin{array}{l}\text { SERVIÇOS SOCIAIS } \\
\text { (EDUCACÃO, SAÚDE, TRABALHO } \\
\text { E PREVIDÊNCIA SOCIAL) }\end{array}$ \\
\hline
\end{tabular}




\section{GrÁfICO I}

Número de processos distribuídos e julgados nos tribunais estaduais no período compreendido entre 1990 e $2004^{*}$

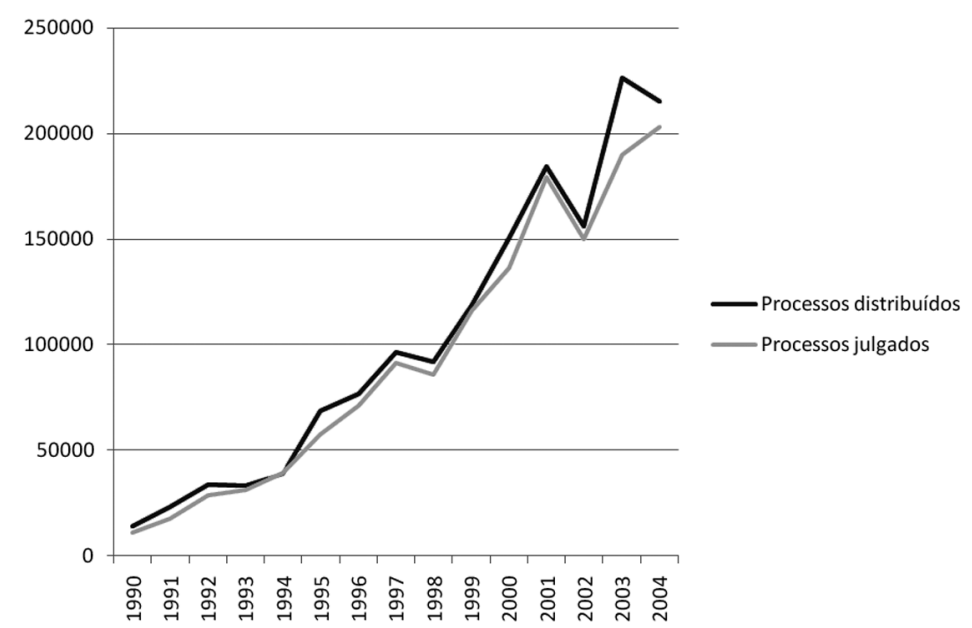

* 2004 é o último ano da série por ser o último sobre o qual o Conselho Nacional de Justiça possui informações.

\section{QUADRO 3}

Sumário das pesquisas sobre tempo da justiça com ênfase na duração dos processos de homicídio doloso

\begin{tabular}{llrl} 
LOCALIDADE & $\begin{array}{l}\text { PERÍODO } \\
\text { ANALISADO }\end{array}$ & TEMPO (DIAS) & $\begin{array}{r}\text { REFERÊNCIA } \\
\text { BIBLIOGRÁFICA }\end{array}$ \\
\hline ESTADO DE SÃO PAULO & $1980-1989$ & 2.230 & PINHEIRO ET AL. (1999) \\
ESTADO DE SÃO PAULO & $1990-1998$ & 983 & VARGAS, RIBEIRO \\
E BLATAVISK (2005) & BATITUCCI, CRUZ \\
EIDADE SILVA (2006)
\end{tabular}

REFERÊNCIA - CÓDIGO DE PROCESSO PENAL

RÉU PRESO 


\section{TABELA I}

Cargos de juízes previstos em lei e providos, segundo a população, em 1998* (Informações relativas à justiça comum de primeiro grau)

\begin{tabular}{|c|c|c|c|c|c|c|}
\hline UF & $\begin{array}{l}\mathbf{N}^{\mathrm{O}} \text { DE } \\
\text { HABITANTES }\end{array}$ & $\begin{array}{l}\text { CARGOS } \\
\text { PREVISTOS } \\
\text { EM LEI }\end{array}$ & $\begin{array}{l}\text { CARgos } \\
\text { PROVIDOS }\end{array}$ & $\begin{array}{l}\mathrm{N}^{\mathrm{O}} \text { DE } \\
\text { HABITANTES } \\
\text { PARA CADA JUIZ } \\
\text { PREVISTO EM LEI }\end{array}$ & $\begin{array}{l}\mathrm{N}^{\mathrm{O}} \text { DE } \\
\text { HABITANTES } \\
\text { PARA CADA } \\
\text { JUIZ PROVIDO }\end{array}$ & $\begin{array}{l}\text { PERCENTUAL } \\
\text { DE CARGos } \\
\text { DE JUÍzeS } \\
\text { NÃo OCUPADO }\end{array}$ \\
\hline$A C$ & 514.050 & 95 & 28 & 5.411 & 18.359 & $71 \%$ \\
\hline$A L$ & 2.688 .117 & 256 & 137 & 10.500 & 19.621 & $46 \%$ \\
\hline$A M$ & 2.520 .684 & 209 & 128 & 12.061 & 19.693 & $39 \%$ \\
\hline AP & 420.834 & 64 & 47 & 6.576 & 8.954 & $27 \%$ \\
\hline $\mathrm{BA}$ & 12.351 .268 & 562 & 361 & 21.977 & 34.214 & $36 \%$ \\
\hline CE & 7.013.376 & 332 & 330 & 21.125 & 21.253 & $1 \%$ \\
\hline DF & 1.923 .406 & 323 & 153 & 5.955 & 12.571 & $53 \%$ \\
\hline ES & 2.895 .547 & 350 & 212 & 8.273 & 13.658 & $39 \%$ \\
\hline $\mathrm{GO}$ & 4.744.174 & 373 & 196 & 12.719 & 24.205 & $47 \%$ \\
\hline MA & 5.356 .853 & 216 & 194 & 24.800 & 27.613 & $10 \%$ \\
\hline MG & 17.100 .314 & 820 & 696 & 20.854 & 24.569 & $15 \%$ \\
\hline MS & 1.995 .578 & 130 & 97 & 15.351 & 20.573 & $25 \%$ \\
\hline MT & 2.331 .663 & 203 & 119 & 11.486 & 19.594 & $41 \%$ \\
\hline PA & 5.768 .476 & 240 & 137 & 2 & 42.106 & $43 \%$ \\
\hline PB & 3.353 .624 & 179 & 171 & 18.735 & 19.612 & $4 \%$ \\
\hline PE & 7.523 .755 & 398 & 337 & 18.904 & 22.326 & $15 \%$ \\
\hline $\mathrm{PI}$ & 2.714 .999 & 177 & 132 & 15.339 & 20.568 & $25 \%$ \\
\hline PR & 9.258 .813 & 466 & 437 & 19.869 & 21.187 & $6 \%$ \\
\hline RJ & 13.681 .410 & 733 & 515 & 18.665 & 26.566 & $30 \%$ \\
\hline $\mathrm{RN}$ & 2.624 .397 & 197 & 113 & 2 & 23.225 & $43 \%$ \\
\hline RO & 1.276 .173 & 98 & 78 & 13.022 & 16.361 & $20 \%$ \\
\hline RR & 260.705 & 19 & 15 & 13.721 & 17.380 & $21 \%$ \\
\hline $\mathrm{RS}$ & 9.866 .928 & 748 & 605 & 13.191 & 16.309 & $19 \%$ \\
\hline $\mathrm{SC}$ & 5.028 .339 & 267 & 258 & 18.833 & 19.490 & $3 \%$ \\
\hline SE & 1.684 .953 & 94 & 94 & 17.925 & 17.925 & $0 \%$ \\
\hline $\mathrm{SP}$ & 35.284 .072 & 1.888 & 1.345 & 18.689 & 26.234 & $29 \%$ \\
\hline TO & 1.107 .803 & 106 & 72 & 10.451 & 15.386 & $32 \%$ \\
\hline $\mathrm{BR}$ & 161.790 .311 & 9.543 & 7.007 & 16.954 & 23.090 & $27 \%$ \\
\hline
\end{tabular}

* Essa foi a informação utilizada na medida em que nem mesmo o Conselho Nacional de Justiça possui informações atualizadas sobre o número de juízes estaduais existentes em cada estado da federação. Nestes termos, a pesquisa de Sadek et al. (2001) apesar de um pouco antiga (1998) ainda continua sendo a melhor fonte de informações. 


\section{TABela 2}

Relação entre número de cargos de juízes previstos e providos e número de processos distribuídos e julgados

Brasil (Informações relativas a 1998)

RAZÃO

VALOR

RAZÃO ENTRE O NO DE JUÍZES PREVISTO E O N DE PROCESSOS DISTRIBUÍDOS 782

RAZÃO ENTRE O N DE JUÍZES PREVISTO E O N DE PROCESSOS JULGADOS 517

RAZÃO ENTRE O Nº DE JUÍZES PROVIDO E O Nº DE PROCESSOS DISTRIBUÍDOS 1.066

RAZÃO ENTRE O Nº DE JUÍZES PROVIDO E O Nº DE PROCESSOS JULGADOS 705

RAZÃO ENTRE O DEFICIT DO NO DE JUÍZES E O NO DE PROCESSOS NÃO JULGADOS 997

FONTE: SADEK ET AL. (2001, P. 35)

\section{QUADRO 3}

Atividades propostas e estágio de realização pelo Conselho Nacional da Magistratura, de 2005 até 2007

PROPOSTA DO CNJ

O QUE JÁ FOI REALIZADO

\begin{tabular}{|c|c|}
\hline $\begin{array}{l}\text { SISTEMA DE PROCESSO JUDICIAL } \\
\text { ELETRÔNICO DO PODER JUDICIÁRIO }\end{array}$ & INSTALADO EM 17 ESTADOS DA FEDERAÇÃO \\
\hline $\begin{array}{l}\text { CERTIFICAÇÃO DIGITAL } \\
\text { (POSSIBILIDADEDE AUTENTICAR } \\
\text { DOCUMENTOS PELO COMPUTADOR) } \\
\end{array}$ & $\begin{array}{l}\text { ASSINATURA DO CONTRATO DA EMPRESA RESPONSÁVEL } \\
\text { PELO DESENVOLVIMENTO DO SISTEMA }\end{array}$ \\
\hline $\begin{array}{l}\text { PORTAL DO CONSELHO } \\
\text { NACIONAL DE JUSTIÇA }\end{array}$ & $\begin{array}{l}\text { JÁ EM FUNCIONAMENTO, APESAR DE SEMPRE POSSUIR } \\
\text { ALGUNS PROBLEMAS TÉCNICOS }\end{array}$ \\
\hline $\begin{array}{l}\text { SISTEMA DE PROCESSO ELETRÔNICO } \\
\text { DO CONSELHO NACIONAL DE JUSTIC̣A }\end{array}$ & $\begin{array}{l}\text { JÁ IMPLEMENTADO PARA OS PROCESSOS QUE TRATAM } \\
\text { DE RECLAMACCÃO POR EXCESSO DE PRAZO E OS PROCEDIMENTOS } \\
\text { DISCIPLINADOS PELA PORTARIA NO } 23 \text { DA PRESIDÊNCIA DO CNJ } \\
\text { E PELA PORTARIA NO } 8 \text { DA CORREGEDORIA NACIONAL DE JUSTIÇA }\end{array}$ \\
\hline $\begin{array}{l}\text { PADRONIZAČ̃̃O TAXONÔMICA DAS } \\
\text { TABELAS BÁSICAS DE CLASSES, } \\
\text { MOVIMENTAÇÕES E ASSUNTOS }\end{array}$ & $\begin{array}{l}\text { A ETAPA PRINCIPAL DO PROJETO FOI CONCLUÍDA COM A EDIÇÃO } \\
\text { DA RESOLUÇÃO NO } 46 \text { DO CONSELHO NACIONAL DE JUSTIÇA, } \\
\text { DE 18.12.2007, QUE CRIOU AS TABELAS PROCESSUAIS UNIFICADAS } \\
\text { DO PODER JUDICIÁRIO }\end{array}$ \\
\hline $\begin{array}{l}\text { NUMERAÇÃO ÚNICA PARA } \\
\text { IDENTIFICAÇÃO DO PROCESSO JUDICIAL }\end{array}$ & NÃO INICIADO \\
\hline $\begin{array}{l}\text { CRIAÇÃO DO DOMÍNIO "JUS.BR" PARA } \\
\text { OS TRIBUNAIS DE JUSTIÇA DE TODO } \\
\text { O PAÍS (EM DETRIMENTO DO GOV.BR) } \\
\end{array}$ & $\begin{array}{l}\text { APROVADO POR MEIO DA RESOLUÇÃO NO 41, DE 11.09.2007, } \\
\text { MAS AINDA NÃO FOI IMPLEMENTADO }\end{array}$ \\
\hline $\begin{array}{l}\text { PADRONIZAÇÃO DOS ENDEREÇOS } \\
\text { ELETRÔNICOS DOS SÍTIOS } \\
\text { DO PODER JUDICIÁRIO }\end{array}$ & $\begin{array}{l}\text { IMPLEMENTADA PELA RESOLUÇÃO NO } 45 \text { DO CNJ, DE 17.12.2007, } \\
\text { QUE DEFINIU OS ENDERECCOS DOS SÍTIOS ELETRÔNICOS (URL) } \\
\text { DOS ÓRGÃOS DO PODER JUDICIÁRIO BRASILEIRO, NOS TERMOS DA } \\
\text { TABELA PADRONIZADA CONSTANTE DOS SEUS ANEXOS continuc }\end{array}$ \\
\hline
\end{tabular}


490 : A EMENDA CONSTITUCIONAL 45 E A QUESTÃO DO ACESSO À JUSTIÇA

RESTRIÇÃO JUDICIAL ONLINE DE VEÍCULOS (SISTEMA RENAJUD)

\begin{tabular}{l|l}
\hline $\begin{array}{l}\text { INFORMATIZACCÃO DOS } \\
\text { CARTÓRIOS EXTRAJUDICIAIS }\end{array}$ & O GRUPO DE TRABALHO PARA ANÁLISE DA TEMÁTICA JÁ FOI INSTITUÍDO \\
\hline BANCO DE SOLUÇÕES DO PODER JUDICIÁRIO & $\begin{array}{l}\text { JÁ ESTÁ DISPONÍVEL AOS TRIBUNAIS, TANTO PARA CADASTRO } \\
\text { DAS SUAS SOLUÇÕES DE INFORMÁTICA QUANTO PARA CONSULTA } \\
\text { E ADOÇÃO DAS SOLUÇÕES DISPONIBILIZADAS }\end{array}$ \\
\hline
\end{tabular}

BANCO DE DADOS DA

POPULAÇÃO CARCERÁRIA

EM FASE DE IMPLEMENTAÇÃO NOS ESTADOS DE SÃO PAULO, RIO DE JANEIRO, GOIÁS, BAHIA, SERGIPE E ESPÍRITO SANTO

REDE NACIONAL DO JUDICIÁRIO

INTEGRARÁ O SUPREMO TRIBUNAL FEDERAL

- STF; CONSELHO NACIONAL DE JUSTICSA - CNJ;

SUPERIOR TRIBUNAL DE JUSTIÇA - STJ́; TRIBUNAL SUPERIOR

DO TRABALHO - TST; CONSELHO DA JUSTICCA FEDERAL

- CJF; OS 24 TRIBUNAIS REGIONAIS DO TRÁBALHO - TRTS;

OS 5 TRIBUNAIS REGIONAIS FEDERAIS - TRFS; E OS 27 TRIBUNAIS

DE JUSTICCA DOS ESTADOS E DO DISTRITO FEDERAL

E TERRITÓRIOS - TJ. AINDA NÃO FOI IMPLEMENTADA

ACESSO À BASE DE DADOS DA RFB - INFOJUD ACESSO AOS DADOS DA SECRETARIA DA RECEITA FEDERAL DO BRASIL. JÁ IMPLEMENTADO

LIQUIDAÇÃO ELETRÔNICA DE PROCESSOS

ESTÁ SENDO DESENVOLVIDO, NA SUA ETAPA INICIAL, COM O BANCO DO BRASIL E A CAIXA ECONÔMICA FEDERAL. NA ETAPA SEGUINTE, SERÁ ESTENDIDO ÀS DEMAIS INSTITUICCÕES FINANCEIRAS QUE MANTENHAM RELACIONAMENTO DE CONTAS JUDICIAIS DE DEPÓSITOS COM O PODER JUDICIÁRIO

CADASTRO DE CLIENTES DO SISTEMA FINANCEIRO NACIONAL

DESENVOLVIDO PELO BANCO CENTRAL DO BRASIL PARA ATENDER À DISPOSIÇÃO DA LEI NO 10.701/2003, COM VISTAS A FACILITAR INVESTIGAÇÕES E AC̣ÕES DESTINADAS A COMBATER A CRIMINALIDADE. O INTUITO É POSSIBILITAR, POR INTERMÉDIO DO CNJ, A DIVULGAÇÃO E A DISPONIBILIZAÇÃO DESSE SISTEMA AOS TRIBUNAIS BRASILEIROS

CADASTRO NACIONAL DE BENS APREENDIDOS

FOI CONSTITUÍDO UM GRUPO DE TRABALHO, MAS AINDA NÃO FOI IMPLEMENTADO

CADASTRO NACIONAL DE ADOÇÃO

JÁ FOI REALIZADA UMA JORNADA DE TRABALHO QUE REUNIU OS TRIBUNAIS DE JUSTICCA DE TODOS OS ESTADOS. NA OCASIÃO, TAMBÉM FORAM DEBATIDOS OS GRANDES EIXOS OPERACIONAIS QUE GARANTIRÃO EFICIÊNCIA, TRANSPARÊNCIA E CONFIABILIDADE À FERRAMENTA

CADASTRO NACIONAL DE CONDENADOS POR ATO DE IMPROBIDADE ADMINISTRATIVA

FOI CONSTITUÍDO UM GRUPO DE TRABALHO, MAS AINDA NÃO FOI IMPLEMENTADO

COLABORAÇÃO COM O SISTEMA DE RECURSO EXTRAORDINÁRIO ELETRÔNICO

FOI CONSTITUÍDO UM GRUPO DE TRABALHO, MAS AINDA NÃO FOI IMPLEMENTADO

MOVIMENTO NACIONAL PELA CONCILIAÇÃO

JÁ FORAM REALIZADAS AS SEGUINTES ATIVIDADES:

DIA DE CONCILIAÇÃO; PROJETO TREINAMENTO EM CONCILIAÇÃO; PROJETO DE TRATAMENTO DE SITUAÇÕES DE SUPERENDIVIDAMENTO; PROJETO CENTRO JUDICIAL DE CONCILIACCÃO; E PROJETO DE CONCILIAÇÃO PARA OS EXECUTIVOS FISCÁIS ESTADUAIS

FONTE: RELATÓRIO DE GESTÃO (2005-2007) DO CONSELHO NACIONAL DE JUSTIC̣A. COMPILAÇÃO DO AUTOR. 


\section{Ludmila Ribeiro}

Rua Gal. Ribeiro da Costa, 107, apt 501

Leme - 22010-050

Bacharel em Direito (UFMG) Rio de Janeiro - RJ - Brasil ludmila.ribeirolgmail.com 